\title{
THE INFLUENCE OF TECHNICAL INFRASTRUCTURE ON THE ROUNDABOUT AREAS DEVELOPMENT
}

\author{
Jakub KOSTECKI ${ }^{1}$, Andrzej GREINERT ${ }^{2}$, Ewelina OWOC $^{3}$ \\ Uniwersytet Zielonogórski, Zielona Góra, Poland
}

\begin{abstract}
The article presents the analysis of roundabouts design aspects including the location of underground and overground infrastructure. Authors also undertake an attempt to assess the existing situation with planning conditions. Many differences depended on the roundabout size, location, surroundings, natural conditions, landform technology used were noted. Roundabouts design should include both the natural arrangements and art installations, increasing the area of urban green areas in parallel using the area as a place for works of art exposure. For Zielona Góra urban area this is of particular importance because of the multitude of roundabouts and their good position in the city structure.
\end{abstract}

Keywords: roundabout, land development, landform, hard infrastructure

\section{INTRODUCTION}

One of the inevitable consequences of the progress of civilization and the rise in well-being of the society is to increase the number of vehicles which run on the roads. According to [12], the total number of cars in Poland (passengers cars and lorries) was 19292000, but in Zielona Gora 518328 [13] vehicles were

\footnotetext{
${ }^{1}$ Corresponding author: University of Zielona Góra, Faculty of Building, Architecture and Environmental Engineering, Z. Szafrana st 1, 65-516 Zielona Góra, Poland, e-mail: j.kostecki@iis.uz.zgora.pl, tel.+48683282407

2 Corresponding author: University of Zielona Góra, Faculty of Building, Architecture and Environmental Engineering, Z. Szafrana st 1, 65-516 Zielona Góra, Poland, e-mail: a.greinert@iis.uz.zgora.pl, tel.+4868328 2680

3 graduate student of the Faculty of Civil Engineering, Architecture and the Environment at University of Zielona Gora
} 
registered. Some of the vehicles passing daily through the streets of Zielona Góra are registered in surrounding districts.

Crossings with traffic lights are a very good solution, but in case of accident or deactivation of the lights can be cause of collisions and accidents. The progress of civilization requires the use of newer and newer solutions to improve safety on the roads. One of the solution is the increasing use of crossroads with the centrally located island and one-way drive direction, so called roundabouts.

According to [18], a roundabout design must ensure good traffic conditions for the increasing number of vehicles, integrate itself with the surroundings, and minimize traffic impact to the environment. Good design should not necessarily limited to ensure good traffic conditions. Also the proper development of the central island and the surroundings, maintaining biodiversity should be an important part of consideration.

Selection of plants for roundabout does not depend merely on the concept of the designer and on the natural conditions. Significant impact on the selection of plants affected technical infrastructure across the central island of roundabouts and adjacent areas. These elements are effectively limiting the use of plants and other forms of design.

\section{HARD INFRASTRUCTURE}

Roundabouts can be divided into a number of criteria, but the most popular seems to be diameter of the central island. Using these criteria there can be distinguished: mini, small, medium and large roundabouts. However, discrepancies arise with defining the size of the central island, as shown in Tab. 1.

Tab. 1. Division of roundabouts size of the central island

\begin{tabular}{|l|c|c|c|c|}
\hline $\begin{array}{c}\text { Roundabout } \\
\text { type }\end{array}$ & $\begin{array}{c}\text { Size } \\
\text { defined by } \\
{[19], \mathrm{m}}\end{array}$ & $\begin{array}{c}\text { Size defined } \\
\text { by [20], } \\
\text { built-up area, } \mathrm{m}\end{array}$ & $\begin{array}{c}\text { Size defined } \\
\text { by [20], } \\
\text { undeveloped area, } \mathrm{m}\end{array}$ & $\begin{array}{c}\text { Size } \\
\text { defined } \\
\text { by [12], } \mathrm{m}\end{array}$ \\
\hline Mini & $3-5$ & $4-10$ & - & $<4$ \\
\hline Small & $11-28$ & $10(5)-28$ & $15-28$ & $4-25$ \\
\hline Medium & $28-50$ & $25-37$ & $25-47$ & - \\
\hline Big & $>50$ & $>37$ & $>50$ & $>25$ \\
\hline
\end{tabular}

The qualification of the size of roundabouts results not only from the size of the central islands, but also a number of traffic lanes. Usually the smaller roundabouts constructs one lane, while the larger ones have two or more lanes. According to the rules of network elements location, in the roads and adjacent roadside verges, the gas-pipes, water supply and sewerage network are arranged 
[3]. In addition there is also infrastructure responsible for transmission of electricity and ICT networks.

The progress made in recent years and taking care of spatial planning order means that a growing part of the network is placed underground. Depending on the type of network, very different is the depth and method of the foundation [18].

Important for the plant growth seems to be the height of curbs, which on the one hand separate vehicles from the green spaces, on the other also protect them from excessive chemicals which can migrate from the road surface in summer and winter months during maintenance clean of roads $[4,5,6]$.

\section{BIOLOGICAL DEVELOPMENT}

Plants used for biological development of roundabouts should be selected by complying many factors, including i.a.:

- size of central island,

- expected effects,

- plants tolerance to urban conditions,

- run of hard infrastructure,

- financial outlays on the maintenance of green.

During the plant selection attention should be paid primarily on their size -they should be tailored to the size of the roundabout and create a coherent composition. It is assumed that the low visibility of the plant should not exceed $70 \mathrm{~cm}$ [15]. Plants used for biological housing should have a high resistance to air pollution and have relatively small habitat requirements -this is related to anthropogenically transformed land, which often appear in admixture building materials (rubble), air-water properties of soils are disrupted, the soil is too dense and overnormative saline $[4,15]$. Herbaceous and annual plants as well as bare ground are more vulnerable to stress of presence of heavy metals. According $[4,5,6]$ increase the concentrations of heavy metals $(\mathrm{Pb}, \mathrm{Zn}, \mathrm{Cu})$ were observed $10 \mathrm{~m}$ from the edge of the roadway.

Many authors $[18,19]$ draw attention to the fact that the central island should stand out against the asphalt - especially in the case of small roundabouts. It therefore seems reasonable using, as far as possible - especially in low lighting roundabouts, plants with colorful or bright leaves.

Landscape architects must choose between permanent plantings (perennials), periodic (annual plants) or mixed (supplemented by annuals and perennials). Selection of plants is extremely important, especialy when hard infrastructure runs across the central island of the roundabout -perennial plants compared to annual plants are characterized by much larger root systems and bigger annuals growing, which can lead to disruption and or even failure of different types of 
infrastructure. Therefore, before planting design chamber studies and site visit should be made, and only on this basis designer shell start matching plants of the area.

As the main errors in the design of urban development: lack of awareness and knowledge of designing and managing green spaces are mentioned also there is no due supervision during and after execution of works [16].

Due to the management of the central island roundabouts can be divided into:

- undeveloped roundabout (with wild growing plants), (B),

- developed roundabout (with the planned plants) (Z).

Additionally, roundabouts developed can be divided into:

- roundabout overgrown with low plants (herbaceous plants, perennials, flowers), (N)

- roundabout overgrown with average plants (shrubs and dwarf shrubs), (S),

- roundabout overgrown with high plants (trees), (W)

- roundabout with mixed plants $(\mathrm{M})$.

\section{ZIELONA GÓRA -A CASE STUDY}

In Zielona Gora, there are 26 roundabouts. A detailed list of locations is summarised in Tab. 2, the location on the background of the city plan is shown in Fig. 1.

Tab. 2. Summary of rondabouts location in Zielona Góra

\begin{tabular}{|c|l|}
\hline No. & \multicolumn{1}{|c|}{ Cross roads } \\
\hline 1 & Al. Wojska Polskiego, Road No 27, Road No 32 \\
\hline 2 & Trasa Północna, Al. Zjednoczenia, Road No 32, Road No 280 \\
\hline 3 & Trasa Północna, Stefana Batorego, Road No 281 \\
\hline 4 & Trasa Północna, Franciszka Rzeźniczaka, Road No 32 \\
\hline 5 & Trasa Północna, Sulechowska, Poznańska \\
\hline 6 & Stefana Batorego, Energetyków, Obywatelska \\
\hline 7 & Al. Wojska Polskiego, Leona Wyczółkowskiego, Prosta \\
\hline 8 & Prosta, Działkowa, Zacisze \\
\hline 9 & Stefana Batorego, Dworcowa \\
\hline 10 & Dworcowa, Ułańska \\
\hline 11 & Dworcowa, Sulechwoska, Gen. Józefa Bema \\
\hline 12 & Bolesława Chrobrego, Westerplatte, Sulechowska \\
\hline 13 & Stanisława Wyspiańskiego, Sulechowska \\
\hline 14 & Stanisława Wyspiańskiego, Bolesława Chrobrego, Al. Niepodległości \\
\hline 15 & Szosa Kisielińska, Kętrzyńska, Osiedle Pomorskie \\
\hline 16 & Al. Wojska Polskiego, Dąbrówki, Zjednoczenia \\
\hline 17 & Podgórna, Plac Piłsudzkiego \\
\hline 18 & Lużycka, Stefana Wyszyńskiego \\
\hline
\end{tabular}



AREAS DEVELOPMENT

\begin{tabular}{|c|l|}
\hline 19 & Stanisława Moniuszki, 1 Maja, Jaskółcza, Wiśniowa \\
\hline 20 & Jaskółcza, Ogrodowa \\
\hline 21 & Ogrodowa, Fabryczna \\
\hline 22 & Sienkiewicza \\
\hline 23 & Stefana Wyszyńskiego, Ptasia \\
\hline 24 & Żurawia, Botaniczna, Tatrzańska, Racławicka \\
\hline 25 & Botaniczna, Nowojędrzychowska \\
\hline 26 & Makowa, Zbozowa, Jędrzychowska, Road No 283 \\
\hline
\end{tabular}

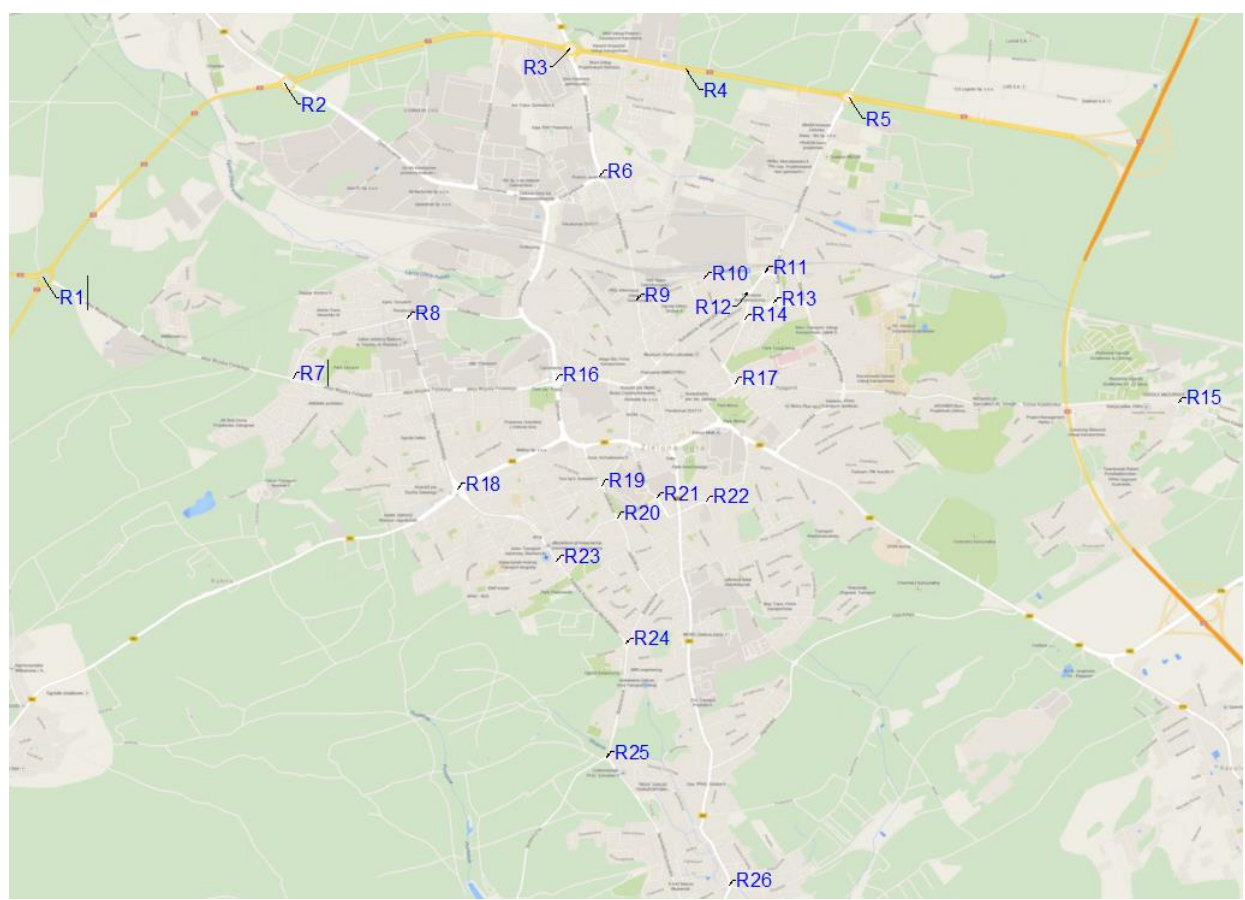

Fig. 1. Location of roundabouts in Zielona Góra [22]

Parameters and characteristics of roundabouts in Zielona Gora are summarized in tab. 3.

Tab. 3. Summary of rondabouts features in Zielona Góra

\begin{tabular}{|c|l|c|c|c|}
\hline No. & Hard Infrastructure $^{1}$ & $\begin{array}{c}\text { Int. (Ext.) } \\
\text { roundabout } \\
\text { diameter, } \mathrm{m}\end{array}$ & $\begin{array}{c}\text { No. } \\
\text { of lanes }\end{array}$ & \begin{tabular}{c} 
Land $_{\text {development }}^{2}$ \\
\hline 1
\end{tabular} \\
$\begin{array}{l}\text { K -undefined (3x), 200 (2x), } \\
250(2 \mathrm{x}), \text { Kd 250 (1x), En (1x), } \\
\text { T-undefined (1x) }\end{array}$ & $100,0(118,0)$ & 2 & B, N \\
\hline 2 & n.d. & n.d. & 2 & B, N \\
\hline 3 & Ko 1600 (1x), 1800 (1x), Ks & $90,0(108,0)$ & 2 & Z, B, \\
\hline
\end{tabular}




\begin{tabular}{|c|c|c|c|c|}
\hline & $\begin{array}{l}600(1 \mathrm{x}), \mathrm{Kd} 200(2 \mathrm{x}), \mathrm{Wo} 400 \\
(1 \mathrm{x}), \mathrm{Gn} \text {-undefined }(1 \mathrm{x}), \text { En } \\
(3 \mathrm{x}), \mathrm{T} 2(1 \mathrm{x})\end{array}$ & & & M: NSW \\
\hline 4 & n.d. & $54,5(68,0)$ & 2 & Z, M: NS \\
\hline 5 & $\begin{array}{l}\text { Ks } 315(1 \mathrm{x}), 500(1 \mathrm{x}), \mathrm{Kd} 160 \\
(1 \mathrm{x}), 200(3 \mathrm{x}), 400(1 \mathrm{x}), 1400 \\
(1 \mathrm{x}), \text { Wo } 600(1 \mathrm{x})-\text { nieczynny, } \\
\text { En }(15 \mathrm{x}), \text { Cn } 2 \mathrm{x} 600(1 \mathrm{x})\end{array}$ & $78,0(80,0)$ & 2 & $\mathrm{~B}, \mathrm{~N}$ \\
\hline 6 & n.d. & $20,0(39,0)$ & 2 & Z, M: NS \\
\hline 7 & $\begin{array}{l}\text { Ko } 600(1 \mathrm{x}), \text { Wo } 80(1 \mathrm{x}) \text {, Ew } \\
(1 \mathrm{x}) \text {, Es }(2 \mathrm{x}), \text { En }(2 \mathrm{x}), \mathrm{T} 2(2 \mathrm{x})\end{array}$ & $15,0(20,0)$ & 1 & $\begin{array}{l}\text { Z, B, M: } \\
\text { NSW }\end{array}$ \\
\hline 8 & $\begin{array}{l}\text { Ko } 1600(1 x), 300(1), \text { Kd } 300 \\
(2 x), \text { Wo } 800(1 x), \text { Gn }(1 x), \text { Es } \\
(1 x), \text { En }(3 x), T 1(1 x)\end{array}$ & $15,5(20,0)$ & 1 & Z, M: NSW \\
\hline 9 & $\begin{array}{l}\text { Ko } 300(1 \mathrm{x}), \text { Ks } 150(1 \mathrm{x}), \text { Wo } \\
(1 \mathrm{x}), \text { Gn (1x), En }(2 \mathrm{x}), \text { Cn } \\
2 \mathrm{x} 400(1 \mathrm{x})\end{array}$ & $15,5(20,0)$ & 1 & Z, M: NSW \\
\hline 10 & $\begin{array}{l}\text { Ko } 1200(1 \mathrm{x}), \mathrm{Kd} 200(1 \mathrm{x}) \\
250(1 \mathrm{x}), \mathrm{Wo} 100(2 \mathrm{x}), 110 \\
(1 \mathrm{x}), \mathrm{Gn} 80(1 \mathrm{x}), 100(2 \mathrm{x}), \text { En } \\
(2 \mathrm{x}) \\
\text { T -undefined }(1 \mathrm{x}),\end{array}$ & $12,8(17,8)$ & 1 & Z, B, M: NS \\
\hline 11 & $\begin{array}{l}\text { Kd } 200(1 \mathrm{x}), 500(1 \mathrm{x}), \mathrm{G}- \\
\text { undefined }(1 \mathrm{x}), \mathrm{Gn} 100(2 \mathrm{x}) \\
160(1 \mathrm{x}), \mathrm{En}(7 \mathrm{x})\end{array}$ & $18,0(22,0)$ & 1 & Z, M: NS \\
\hline 12 & $\begin{array}{l}\text { Kd } 400(1 x), \text { Wo } 160(1 x), 200 \\
(1 x), \text { En }(6 x)\end{array}$ & $15,5(20,0)$ & 1 & Z, S \\
\hline 13 & $\begin{array}{l}\mathrm{K} \text {-undefined (1x), Kd } 150 \\
(1 \mathrm{x}), 200(1 \mathrm{x}), \operatorname{En}(4 \mathrm{x})\end{array}$ & $16,8(20,8)$ & 1 & Z, M: NSW \\
\hline 14 & $\begin{array}{l}\text { Ko } 300(1 \mathrm{x}), \text { Ks } 150(1 \mathrm{x}), \text { Wo } \\
40(1 \mathrm{x}), 100(1 \mathrm{x}), 150(1 \mathrm{x}), \mathrm{Gn} \\
100(1 \mathrm{x}) \text {-closed, En }(1 \mathrm{x}), \mathrm{T} 1 \\
(2 \mathrm{x}), \mathrm{T} 3(2 \mathrm{x})\end{array}$ & $17,5(20,0)$ & 1 & Z, M: SW \\
\hline 15 & n.d. & $22,5(28,0)$ & 1 & Z, M: NS \\
\hline 16 & $\begin{array}{l}\text { Ko } 1200(1 \mathrm{x}), 1600(1), \mathrm{Kd}- \\
\text { undefined }(1 \mathrm{x}), \mathrm{Kd} 150(1 \mathrm{x}), \\
\text { Wo } 32(1 \mathrm{x}), 150(1 \mathrm{x}), \operatorname{En}(7 \mathrm{x})\end{array}$ & $30,0(54,0)$ & 2 & $\mathrm{~B}, \mathrm{~N}$ \\
\hline 17 & $\begin{array}{l}\text { Ko } 400(1 \mathrm{x}), \text { Wo } 80(2 \mathrm{x}), 100 \\
(2 \mathrm{x}), \mathrm{Gn} 160(4 \mathrm{x}), \text { En }(2 \mathrm{x}), \mathrm{T} 1 \\
(1 \mathrm{x})\end{array}$ & $26,0(30,0)$ & 1 & Z, M: NS \\
\hline 18 & $\begin{array}{l}\text { Ko } 250(1 x), \text { Kd (1x), Wo } 200 \\
(1 x), \operatorname{En}(2 x)\end{array}$ & $25,0(29,0)$ & 1 & Z, M: SW \\
\hline 19 & $\begin{array}{l}\text { Ko } \text {-undefined }(1 \mathrm{x}), \text { Ko } 200 \\
(1 \mathrm{x}), 500(1 \mathrm{x}), \mathrm{Kd} 400(1 \mathrm{x}),\end{array}$ & $16,0(21,0)$ & 1 & $\mathrm{~B}, \mathrm{~N}$ \\
\hline
\end{tabular}




\begin{tabular}{|c|c|c|c|c|}
\hline & $\begin{array}{l}\text { Wo } 100(1 \mathrm{x}), 400(1 \mathrm{x}), \text { Gn } 100 \\
(1 \mathrm{x}), \mathrm{En}(1 \mathrm{x}), \mathrm{Cw} 406(2 \mathrm{x})\end{array}$ & & & \\
\hline 20 & $\begin{array}{l}\text { Ko } 200(1 \mathrm{x}), 400(1 \mathrm{x}), \mathrm{Kd} 350 \\
(1 \mathrm{x}), \mathrm{W} \text {-undefined } 225(1 \mathrm{x}), \\
\text { Wo } 100(1 \mathrm{x}), \mathrm{Gn} 80(1 \mathrm{x}), 150 \\
(1 \mathrm{x}), \text { En }(3 \mathrm{x}), \mathrm{T} \text {-undefined } \\
(1 \mathrm{x})\end{array}$ & $13,5(19,0)$ & 1 & $\mathrm{~B}, \mathrm{~N}$ \\
\hline 21 & $\begin{array}{l}\mathrm{K} \text {-undefined }(2 \mathrm{x}), \mathrm{Ko} 300 \\
(1 \mathrm{x}), 500(1 \mathrm{x}), \mathrm{Kd} 200(1 \mathrm{x}), \mathrm{Gn} \\
100(3 \mathrm{x}), 160(1 \mathrm{x}) \text {-closed, T2 } \\
(1 \mathrm{x})\end{array}$ & $10,0(13,0)$ & 1 & $\mathrm{~B}, \mathrm{~N}$ \\
\hline 22 & n.d. & $20,0(31,5)$ & 1 & Z, M: N \\
\hline 23 & $\begin{array}{l}\text { Ko } 400(1 \mathrm{x}), 500(1 \mathrm{x}), \mathrm{Kd} 200 \\
(1 \mathrm{x}), \text { Wo } 150(2 \mathrm{x}), \text { Gs } 225 \\
(1 \mathrm{x}), \text { Gn } 250(1 \mathrm{x}), \text { Es }(2 \mathrm{x}), \text { En } \\
(2 \mathrm{x})\end{array}$ & $18,5(24,0)$ & 1 & $\mathrm{Z}, \mathrm{M}: \mathrm{S}, \mathrm{W}$ \\
\hline 24 & $\begin{array}{l}\text { K -undefined } 225(1 \mathrm{x}), \mathrm{Ko} 800 \\
(1 \mathrm{x}), \mathrm{Ks} 110(1 \mathrm{x}), 200(1 \mathrm{x}), \mathrm{Kd} \\
400(1 \mathrm{x}), \text { Wo } 65(1 \mathrm{x}), 150(1 \mathrm{x}), \\
\mathrm{G} \text {-undefined } 90(1 \mathrm{x}) \text {-closed, } \\
100(1 \mathrm{x}) \text {-closed, Gn } 150(1 \mathrm{x}), \\
160(1 \mathrm{x}) \text {-closed, Es }(2 \mathrm{x}), \mathrm{En} \\
(5 \mathrm{x}), \mathrm{T} \text {-undefined }(1 \mathrm{x}), \mathrm{T} 2 \\
(2 \mathrm{x})\end{array}$ & $\begin{array}{l}23,0-38,5 \\
(27,0-43,0)\end{array}$ & 1 & $\mathrm{Z}, \mathrm{M}: \mathrm{S}, \mathrm{W}$ \\
\hline 25 & Kd $200(3 x)$, En (4x) & $22,0(26,0)$ & 1 & Z, B, M: N,S \\
\hline 26 & n.d. & $10,0(24,0)$ & 1 & $\mathrm{Z}, \mathrm{SL}$ \\
\hline
\end{tabular}

${ }^{1} \mathrm{~K}$ - sewer (undefined), Ko - sewer (rain and sanitary), Ks - sanitary sewer, Kd -Rain sewer, W - water supply (undefined), Wo - general water supply, G - gas (undefined), Gs - midium pressure gas, Gn - low pressure gas, EW - high voltage electricity, ES - medium voltage electricity, EN - low voltage electricity, $\mathrm{Cw}$ - high pressure heating, $\mathrm{Cn}$-low pressure heating, T telecommunication (undefined), $\mathrm{T} 1$ - telecommunication (singiel channel drains)

${ }^{2} \mathrm{Z}$-developed roundabout, B - undeveloped roundabout, M - various kind of plants, SL -solid, $\mathrm{N}$-herbaceous vegetation and lawns, $\mathrm{S}$-shroubs and perennial plants, $\mathrm{W}$-trees and shroubs $1 \mathrm{x}$ single pipe/line, $2 \mathrm{x}$-double pipe/line, $3 \mathrm{x}$ - triple pipe/line

The case study has been based on the analysis of design and development of two roundabouts: number 2 (Stefan Batory roundabout) and number 7 (Michał Kaziow roundabout).

Roundabout No. 2 is a large one $\left(\mathrm{D}_{\text {exta }}=108.0 \mathrm{~m}\right)$, located on the outskirts of the city. It's a crossroads of the provincial road No. 281, ringroad (Trasa Północna) and the road leading to the city center (Stefan Batory rd.). Intersection has 2 lanes. Housing of the island can be considered as mixed (M: SW), intentional $(Z)$. This follows from the fact that the surface of the island is covered with meadow-type plants, including: smooth meadow grass (Poa pratensis L.), perennial ryegrass (Lolium perenne L.), field sowthistle (Sonchus arvensis L.), 
sorrel (Rumex acetosella L.), yarrow (Achillea millefolium L.), field bindweed (Convolvulus arvensis L.) and ribwort plantain (Plantago lanceolata L.). At the outer ring of central island places has been planted birch. In some parts mix of thuja (Thuja occidentalis L.), forsythia (Forsythia suspensa (Thunb.) Vahl.) and berberis (Berberis vulgaris L.) can be found. In the middle, in 3 red flower pots grows thuja (Thuja occidentalis L.). View of the roundabout is shown in Fig. 2.

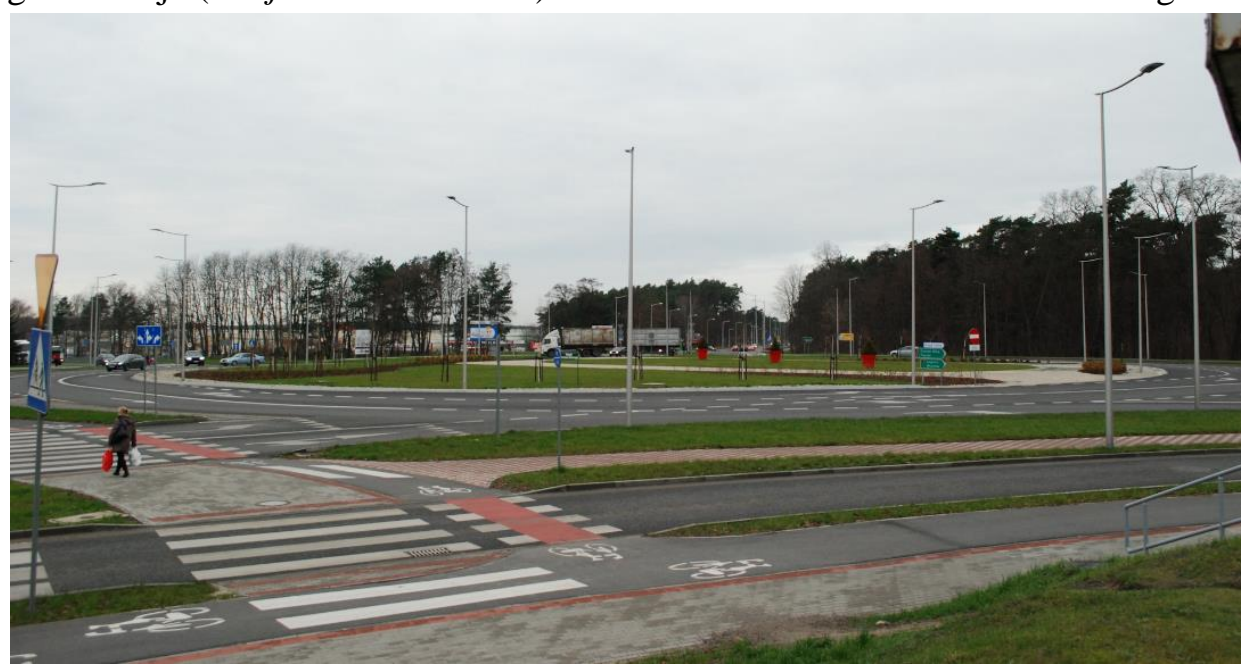

Fig. 2. View of the Stefan Batory roundabout, 2015

Through roundabout number 2 the following infrastructure is running: sewage, water, energy and telecommunications. The greater part of the networks passes through the south-western part of the central island -precisely in that part of them intersect planting vines (Vitis vinifera $\mathrm{L}$.). They are situated approximately $1.6 \mathrm{~m}$ (from the axis of the tree) from the underground low voltage power line and telecommunication drains. Detailed location of the network and planting of greenery is shown in Fig. 3.

Michael Kaziowa roundabout (No. 7) is a small roundabout, with outer diameter Dexta $=20.0 \mathrm{~m}$. It's located near the city center, opposite the train station. It's a crossroads of: Boleslaw Chrobry (2 lanes), Bohaterów Westerplatte (2 lanes) and Sulechowska street (1 lane). The central island is built up the road surface to about $10 \mathrm{~cm}$. Around the central island is a truck aproan made of concrete blocks in a dark color. The area is developed $(\mathrm{Z})$ with middium height plants (S). The island is carefully maintained, there was no weeds. In the central part of the island (around the lighthouse) a ring of Thunberg barberry (Berberis thunbergii DC.) growes. Next to the Thunberg is a ring of the rose "Spevu" (Rosa Lovely Fairy "Spevu"). Between "Spevu" roses, also in the ring, picked 
roses are planted. The outer ring of the island is covered by the creeping juniper (Juniperus horizontalis Moench.). View of the roundabout is shown in Fig. 4. Across the roundabout No. 7 runs: sewage, water pipes and energy cabels. Due to the planned housing of central islands all networks are directly under the plants, as shown in Fig. 5.

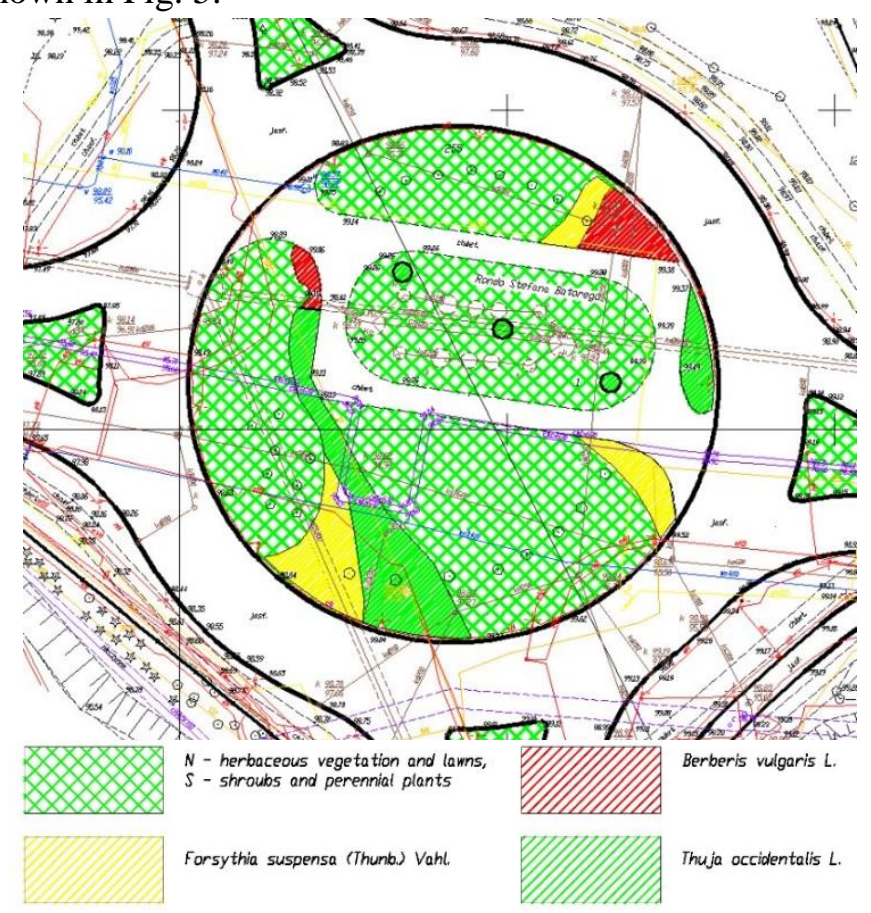

Fig. 3. Run of the hard infrastructure through the central island of Stefan Batory roundabout including plants

Tab. 4. Mean and maximum temperature and rainfall of vegetation season in Zielona Gora [13]

\begin{tabular}{|l|c|c|c|}
\hline Month & $\begin{array}{c}\text { Mean temperature, } \\
{ }^{\circ} \mathrm{C}\end{array}$ & $\begin{array}{c}\text { Max temperature, } \\
{ }^{\circ} \mathrm{C}\end{array}$ & $\begin{array}{c}\text { Mean rainfalls, } \\
\mathrm{mm}\end{array}$ \\
\hline April & 9 & 22 & 20 \\
\hline May & 11 & 21 & 90 \\
\hline June & 17 & 30 & $10-20$ \\
\hline July & 22 & 34 & $90-100$ \\
\hline August & 18 & 29 & 100 \\
\hline September & 12 & 21 & 100 \\
\hline October & 7 & 17 & 10 \\
\hline
\end{tabular}

It was quite surprising that there is no technical solution of plants watering constructing microclimate of roundabouts during the summer. High temperature 
and low precipitation in Zielona Gora of vegetation season for the year 2010, (summarized in Tab. 4.) can lead to dry land, which in turn leads to the withering of vegetation $[4,5,6]$.



Phot. 4. View of the Michał Kaziow roundabout, a) sideview, b) plan view [22]

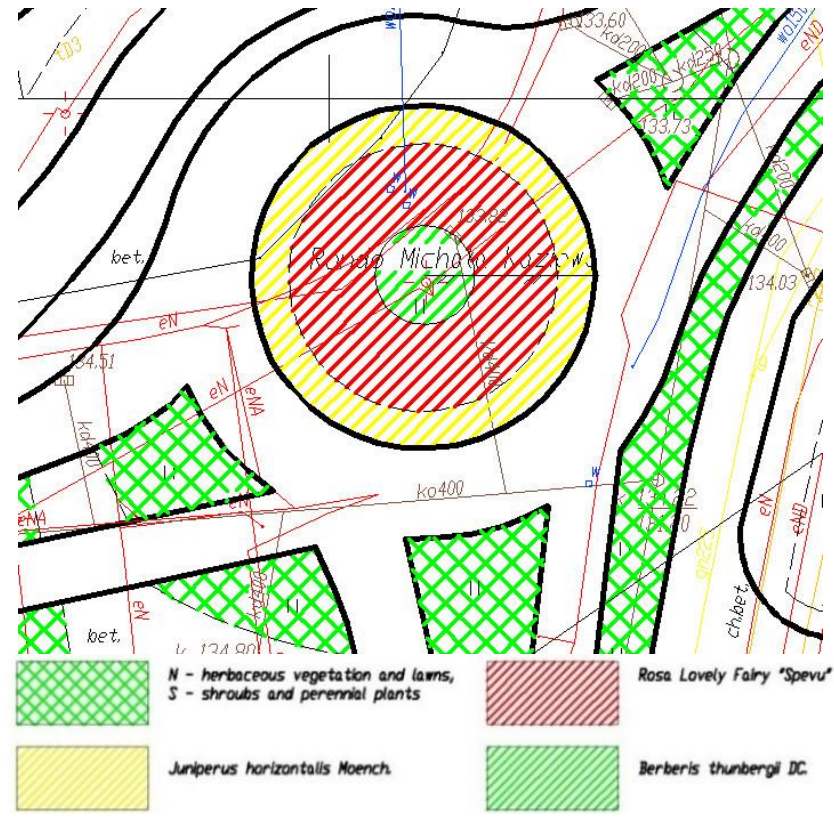

Fig. 5. Run of the hard infrastructure through the central island of Michał Kaziow roundabout, the vegetation has been marked with colour circles 


\section{CONCLUSIONS}

Roundabout as part of the road infrastructure can be seen only in technical terms. Their development then descends into the background, the main aim stays their usefulness and purpose -which is undoubtedly the reduction of vehicle speed while maintaining the fluidity of movement of vehicles and safety of drivers. Because most roundabouts are built in urban areas, their management becomes the aesthetic importance, which manifests itself mainly in the biological housing of central islands [1].

Size of roundabouts depends mainly on their location -a small roundabout generally dominate in the city center, due to limited space, are commonly introduced during the roads work. Large roundabouts, often with two lanes, are placed outside the city (so-called gateway).

To fulfill its mission, roundabout should complete several technical criteria, but primarily the central island should be visible to traffic participant. This can be achieved in many ways, but the simplest seems to be planting bright or lightly pigmented vegetation $[3,15,18,20,21]$. Another advantage, especially for large roundabouts is the ability to use spatial installations (ideologically neutral). Such structures do not require year-round care, may play a role in the completion of low vegetation and be a showcase of the city, which will increase the aesthetic value especially during the growing season $[8,21]$. It is also important, that this objects (especially the large one) have some gaps, which should allow drivers to keep their attention on the road, which in turn will help to reduce the number of collisions [14]. Natural design of roundabout increase acreage of green spaces in the cities. This improves the microclimate and helps to neutralize the negative impact of communication areas [6].

Central islands offer the possibility of an interesting arrangement of space, but a multitude of underground infrastructure effectively limits the number of plants, mainly by the size of the root system. The use of large plants is possible, but quite complicated -avoiding interaction could lead to chaotic plantings that instead of improving the aesthetics, efficient impaired it.

\section{REFERENCES}

1. Burns T., Dolan L.M.J., Whelan P.M., Nairn R., Murphy P.: A Guide to Landscape Treatments for National Road Schemes in Ireland, electronic document http://www.nra.ie/Publications/DownloadableDocumentation/ Environment/file,3481,en.pdf. 
2. Cielecki A.: Projektowanie $i$ funkcjonowanie rond $w$ Poslce - studium przypadków, in: Projektowanie rond. Doświadczenia i nowe tendencje, red. Żurowska J. PiT, Kraków 2010, 93-104.

3. Construction drawings - Landscape drawing practice (ISO 11091:1994).

4. Greinert A., Fruzińska R., Kostecki J., 2013: Urban soils in Zielona Góra. Technogenic soils of Poland ed. by P. Charzyński, P. Hulisz, R. Bednarek. Torun, Polish Society of Soil Science, p. 31-54.

5. Greinert A., Drozdek M.E. (red.), 2015. „Zielona” Zielona Góra -Strategia rozwoju terenów zieleni w mieście Zielona Góra; Wyd. IIŚ WBAIŚ, UZ, p. 1247.

6. Heidt V., Neef M.: Benefits of urban green space for improving climat, in: Ecology, planning, and management of urban forests: international perspectives, Carreiro M.M, Song Y-C., Wu J, red. Springer, 2008, 84-96.

7. Kostecki J., Owoc E.: Sieci przesyłowe $w$ krajobrazie miejskim, Zeszyty naukowe Uniwersytetu Zielonogórskiego Seria Inżynieria Środowiska, 142 (22), OWUZ, Zielona Góra 2011.

8. Lay M.G.: Handbook of Road Technology, Spon Pres, Nowy Jork 2009.

9. McKinney, M.L., 2008: Effects of urbanization on species richness: A review of plants and animals, Urban Ecosyst (2008) 11 (2): p 161-176. doi:10.1007/s11252-007-0045-4.

10. Miętus M., Ustrnul Z., Marosz M., Owczarek M., Biernacik D., Czekierda D., Kilar P., Czernecki B.: Biuletyn monitoringu klimatu Polski, IMGW, Warszawa 2010.

11. Rupprecht C.D.D., Byrne J.A., 2014: Informal Urban Green-Space: Comparison of Quantity and Characteristics in Brisbane, Australia and Sapporo, Japan. PLoS ONE 9(6): e99784. doi:10.1371/journal. pone.0099784.

12. Rocznik statystyczny Rzeczypospolitej Polskiej, Zakłady Wydawnictw Statystycznych,Warszawa 2010.

13. Rocznik Statystyczny Województwa Lubuskiego, US, Zielona Góra 2010.

14. Schurr K.S., Abos-Sanchez J.: Effects of Central Island Landscaping Treatments at Single-Lane Roundabouts, Nebraska 2005, electronic document http://www.ne-ltap.unl.edu/ndor/Roundabout.zip, access 20.09.2011.

15. Skórkowska A.: Rondo jako element krajobrazu miasta, electronic document http://www.zszp.pl/?id=28\&nid=419\&lang=1.

16. Szczecińska A.: Błędy w projektowaniu i zagospodarowaniu terenów zieleni miejskiej, in: Zieleń miast $i$ wsi. Współczesna $i$ zabytkowa, red. Drozdek M.E. Prymasowskie Wydawnictwo Gaudentinum, Gniezno 2009.

17. Szling Z., Pacześniak E.: Odwodnienia budowli komunikacyjnych, OWPW, Wrocław 2004. 
18. Tollazzi T., Mauro R., Guerrieri M., Rencelj M., 2016: Comparative analysis of four new alternative types of roundabouts: "Turbo", "Flower", "Target" and "Four-Flyover" Roundabout, Periodica Polytechnica Civil Engineering, 60(1), pp. 51-60, DOI: 10.3311/PPci.7468.

19. Tracz M., Chodur J., Gaca S., Kieć M., Nosek M., Sonnenberg W., Tracz w.: Wytyczne projektowania skrzyżowań drogowych. Część II Ronda, GDDP, Warszawa 2001.

20. Tracz M.: Ronda w Polsce -stan wiedzy i praktyka, in: Projektowanie rond. Doświadczenia i nowe tendencje, red. Żurowska J. PiT, Kraków 2010, 93104.

21. Zalewski A.: Rondo jako zagadnienie urbanistyczne, in: Projektowanie rond. Doświadczenia i nowe tendencje, red. Żurowska J. PiT, Kraków 2010, 93-104.

22. www.maps.google.pl

\section{WPŁYW INFRASTRUKTURY TECHNICZNEJ NA FORME ZAGOSPODAROWANIA ROND}

\section{Streszczenie}

W artykule przedstawiono analizę obudowy biologicznej rond w Zielonej Górze na tle infrastruktury podziemnej i nadziemnej. Podjęto również próbę oceny zastanej sytuacji $\mathrm{z}$ uwarunkowaniami planistycznymi. Zauważono wiele różnic między rondami, zależnych od ich wielkości, umiejscowienia, otoczenia, warunków przyrodniczych i technologii kształtowania terenu. Ronda powinny zawierać zarówno elementy przyrodnicze, jak instalacje, zwiększając powierzchnię terenów zieleni miejskiej przy równoległym wykorzystaniu powierzchni dla prezentacji dzieł sztuki. Dla Zielonej Góry ma to szczególne znaczenie $\mathrm{z}$ racji mnogości rond i dobrego ich usytuowania w strukturze miasta.

Słowa kluczowe: rondo, zagospodarowanie przyrodnicze, kształtowanie terenu, infrastruktura techniczna

Editor received the manuscript: 21.09 .2016 
